\title{
Identifikasi Kejadian Kecelakaan Kapal Berbasis Analisis Faktor Cuaca dan Citra Satelit (Studi Kasus Tanggal 18 Juni 2018 di Danau Toba)
}

\author{
Diana Cahaya Siregar*, Sulton Kharisma, Bagas Ega Amirul Haq and Regina Dara Ninggar
}

\begin{abstract}
Ringkasan
KM Sinar Bangun IV yang mengangkut penumpang sebanyak 188 orang dan 70 unit kendaaan diberitakan tenggelam di Danau Toba pada hari Senin tanggal 18 Juni 2018. Kejadian itu diprakirakan terjadi akibat adanya kelebihan kapasitas muatan, kondisi cuaca yang buruk, dan human error. Analisis cuaca baik dalam skala global, regional, maupun lokal dilakukan untuk mengetahui kondisi cuaca saat kejadian. Analisis data citra satelit, AWS, dan ARG digunakan untuk mengetahui kondisi cuaca juga. Berdasarkan analisis streamline terdapat shearline di sekitar wilayah Sumatera Utara yang dapat memicu pertumbuhan awan cumuliform khususnya awan Cumulonimbus. Suhu permukaan laut dalam kondisi hangat yaitu berkisar $28-30^{\circ} \mathrm{C}$ sehingga konvektifitas antara atmosfer dan lautan cukup giat. Berdasarkan analisis time series suhu puncak awan dari kanal IR dan VIS, menunjukkan adanya pertumbuhan awan konvektif di sekitar Danau Toba. Pada saat kejadian, wilayah di sekitar Danau Toba sedang terjadi hujan dimana beberapa AWS dan ARG mencatat curah hujan yang mencapai lebih dari $30 \mathrm{~mm} /$ hari.
\end{abstract}

Kata Kunci : cuaca buruk, himawari-8, satelit.

\begin{abstract}
KM Sinar Bangun IV was carrying passengers about 188 people and 70 units of vehicles when it sank in Lake Toba, North Sumatra on Monday, June 18, 2018. The incident was occurred due to overcapacity, bad weather condition, and human error. Meteorological analysis on a global, regional and local scales were used to determine atmospheric dynamics at the time of the event. Meanwhile, Satellite, AWS, and ARG data were used to determine the weather condition. Streamline analysis showed the shear line pattern in Sumatra Island and convergence in North Sumatra. The condition of sea surface temperature was warm enough in the range of $28-30^{\circ} \mathrm{C}$. These conditions triggered for the potential of convective clouds development. Himawari-8 satellite images from IR and VIS channels showed the development of convective clouds in Lake Toba right before the event happened. AWS and ARG measurements around the Lake Toba area recorded precipitation which the value was greater than $30 \mathrm{~mm} /$ day.
\end{abstract}

Keywords: bad weather; himawari-8; satellite.

\section{PENDAHULUAN}

KM Sinar Bangun IV yang diperkirakan membawa penumpang sekitar 188 orang dan kendaraan bermotor 70 unit pada hari Senin tanggal 18 Juni 2018 sekitar pukul 17.00 WIB tenggelam di perairan Danau Toba, Sumatera Utara. Berdasarkan berita online (Tempo

\footnotetext{
${ }^{*}$ Correspondence: siregardianacahaya@gmail.com

Badan Meteorologi, Klimatologi dan Geofisika, Stasiun Meteorologi

Tanjungpinang, JI. Adi Sucipto KM 12.5, Bandara RHF, Tanjungpinang

Timur, Tanjungpinang, Indonesia

Full list of author information is available at the end of the article

${ }^{\dagger}$ Equal contributor
}

Co)[11], tenggelamnya kapal tersebut diprakirakan terjadi akibat kondisi cuaca buruk berupa angin kencang dan gelombang tinggi (ombak besar). Menurut Kepala Pelaksana Badan Penanggulangan Bencana Daerah (BPBD) Kabupaten Samosir, Mahler Tamba menyatakan tenggelamnya Sinar Bangun karena kelebihan kapasitas, cuaca buruk, dan human error sebagaimana yang dimuat dalam berita online (Detik News)[12]. Cuaca buruk dapat terjadi sebagai dampak dari pertumbuhan awan konvektif. Untuk mengetahui faktor yang mempengaruhi cuaca buruk, 
perlu memperhatikan fenomena meteorologi yang terjadi pada skala global, regional, dan lokal (Zakir, dkk., 2010)[10]. Paski (2014)[6] pernah menyebutkan cuaca ekstrem bisa terjadi sebagai dampak dari faktor cuaca skala regional dan lokal seperti efek siklon tropis, eddy, dan daerah shearline. Penelitian ini bertujuan untuk menganalisis kondisi cuaca ketika KM Sinar Bangun IV tenggelam. Analisis cuaca skala global, regional, dan lokal dilakukan untuk mengidentifikasi gangguan cuaca dominan apa yang terjadi pada saat kejadian. Analisa dilakukan secara kualitatif dengan menggunakan data citra satelit Himawari-8 yang merupakan generasi pembaharuan dari MTSAT-2 (Multi-Transpose Satelitte).

Citra satelit Himawari-8 digunakan untuk menginterpretasikan kondisi atmosfer saat KM Sinar Bangun IV tenggelam. Citra satelit dapat menggambarkan luas tutupan awan dan perubahan suhu puncak awan. Pandjaitan dan Andersen (2015)[5] menyatakan satelit Himawari-8 memiliki resolusi temporal tiap 10 menit untuk pengamatan global dan 2.5 menit untuk pengamatan khusus. Penelitian ini akan menggunakan kanal Infra-red (IR) untuk menggambarkan distribusi suhu puncak awan dimana suhu rendah akan divisualisasikan terang dan bagian suhu tinggi terlihat gelap. Kanal IR dapat digunakan dalam menganalisa pertumbuhan awan cumuliform khususnya awan Cumulonimbus yang dapat memicu terjadinya cuaca ekstrem pada saat kejadian. Hidayat, dkk. (2017)[3] menyatakan identifikasi awan Cumulonimbus menggunakan kanal IR ditandai dengan wilayah tutupan awan dengan suhu puncak awan yang rendah berkisar kurang dari $-50^{\circ} C$. Kanal VIS digunakan untuk analisis pertumbuhan awan konvektif yang dapat memicu cuaca buruk. Analisis RGB Day juga digunakan untuk mengetahui pertumbuhan awan konvektif.

\section{METODE PENELITIAN}

Penelitian ini akan mengkaji kondisi cuaca skala global, regional dan lokal. Faktor cuaca skala global yang dianalisis meliputi Indian Ocean Dipole (IOD) yang diakses dari iTacs (Interactive Tool for Analysis of the Climate System), El-Nino Southern Oscillation (ENSO) yang diakses dari www.bom.gov. au, dan Sea Surface Temperature (SST) berupa data analisis dan data anomali dari National Oceanic and Atmospheric Administration (NOAA) yang diakses melalui http://polar.ncep.noaa.gov. Faktor cuaca skala regional yang dianalisis meliputi analisis streamline yang diperoleh dari www.bmkg.go. id dan analisis Madden-Julian Oscilation (MJO) yang diakses dari www.bom.gov. au.
Faktor cuaca skala lokal dianalisis menggunakan data pengamatan permukaan (sinoptik) yang tercatat oleh Automatic Weather Station yang ada di Parapat. Analisis pertumbuhan awan-awan konvektif dapat dilihat juga dari kejadian terjadinya hujan (presipitasi). Analisis curah hujan dilakukan dengan melihat jumlah akumulusai curah hujan harian yang tercatat oleh beberapa Automatic Rain Gauge (ARG) di sekitar wilayah Danau Toba yaitu ARG Simanindo, ARG Raya, ARG Gurgur, ARG Merek, ARG Sidikalang. Data-data tersebut diperoleh dari AWS Centre BMKG. Selanjutnya akan dilakukan analisis kondisi atmosfer dengan menggunakan data citra satelit Himawari-8 kanal IR dengan ekstensi netcdf akan diolah dengan menggunakan GrADS (The Grid Analysis and Display System) untuk melihat suhu puncak awan. Analisis $R G B$ Day Microphysics digunakan untuk melihat perkembangan awan konvektif dimana akan diolah menggunakan aplikasi SATAID. Kanal VIS dengan ekstensi .z juga diolah dengan menggunakan aplikasi SATAID untuk melihat nilai albedo dari awan konvektif yang terbentuk disekitar Danau Toba.

\section{HASIL DAN PEMBAHASAN}

\section{A. Analisis Pengaruh Cuaca Skala Global 1. Indian Ocean Dipole (IOD)}

Gambar 2 menampilkan grafik rangkaian waktu (time series) IOD selama periode bulan Mei hingga Juni 2018. Hampir sepanjang bulan Mei hingga Juni 2018, IOD berada dalam kondisi Netral. Hal tersebut berarti tidak adanya aktivitas IOD yang dapat mempengaruhi kondisi cuaca di Samudera Hindia tropis bagian barat (west box) dan Samudera Hindia tropis bagian timur (east box). IOD dalam kategori Netral menunjukkan tidak adanya penjalaran massa uap air dari Samudera Hindia menuju wilayah Indonesia, atau sebaliknya.

\section{El-Nino Southern Oscillation (ENSO)}

Grafik ENSO yang ditampilkan pada Gambar 3 memiliki kecenderungan dalam kondisi Normal. Nilai indeks Nino 3.4 di bulan Juni 2018 berkisar -0.5 sampai 0. ENSO dalam kondisi Normal menunjukkan pola cuaca di wilayah Samudra Pasifik juga dalam kondisi normal yang berarti kondisi iklim di wilayah Samudera Pasifik Barat tidak terlalu kering maupun terlalu basah jika dibandingkan terhadap normalnya. ENSO dalam kategori Normal menunjukkan tidak adanya penjalaran massa uap air dari Samudera Pasifik menuju wilayah Indonesia, atau sebaliknya. 


\section{Sea Surface Temperature (SST)}

Gambar 4 dan 5 menginterpretasikan bagaimana kondisi SST dan anomali SST. Kondisi suhu permukaan laut di sekitar wilayah timur Sumatera Utara berkisar $28-30^{\circ} \mathrm{C}$. Hal tersebut dapat memicu konvektifitas yang cukup giat antara atmosfer dan lautan. Kondisi tersebut juga didukung dari anomali SST di wilayah tersebut berkisar -0.75 sampai $-0.5^{\circ} C$. SST yang hangat menunjukkan presipitasi tinggi di suatu daerah. Anomali negatif menandakan suhu muka laut lebih dingin dari kondisi normal. Namun dilihat dari kondisi SST yang hangat dapat memicu penambahan massa uap air dari lautan ke atmosfer yang menggumpal menjadi awan-awan konvektif di sekitar wilayah Sumatera Utara.

\section{B. Analisis Pengaruh Cuaca Skala Regional 1. Madden-Julian Oscillaton (MJO)}

Gambar 6 menunjukkan penjalaran MJO dari awal Juni 2018 sampai pertengahan Juli 2018. Di awal bulan Juni 2018, MJO dalam keadaan aktif (di luar lingkaran) namun di pertengahan bulan Juni MJO dalam keadaan tidak aktif. Kondisi tersebut berarti pola cuaca di wilayah Indonesia bagian barat tidak dipengaruhi oleh aktivitas penjalaran MJO. Analisis terhadap Outgoing Longwave Radiation (OLR) untuk pertengahan bulan Juni 2018 juga tidak menunjukkan penjalaran MJO yang aktif di wilayah Indonesia (Gambar 7). Analisis OLR di sekitar wilayah Sumatera Utara pada tanggal 18 Juni 2018 sekitar 160 $180 \mathrm{~W} / \mathrm{m}^{2}$. Nilai OLR tersebut menunjukkan adanya aktivitas konvektif yang giat dimana terdapat banyak awan-awan cumuliform yang terbentuk di wilayah tersebut.

\section{Streamline}

Analisis angin gradien berdasarkan streamline tanggal 18 Juni 2018 (Gambar 8) yang dikeluarkan oleh BMKG menunjukkan adanya sirkulasi siklonik di sebelah barat Pulau Sumatera sehingga memicu terbentuknya daerah belokan angin atau shearline yang dapat menyebabkan perlambatan aliran massa udara. Penumpukan uap air akibat perlambatan aliran massa udara di sekitar shearline memicu pertumbuhan awan konvektif. Selain itu, adanya daerah konvergensi di sekitar Sumatera Utara menyebabkan pertemuan massa udara sehingga terjadi pengangkatan massa udara yang selanjutnya memicu giatnya konvektifitas.

\section{Analisis Pengaruh Cuaca Skala Lokal 1. Analisis Pengamatan Sinoptik}

KM Sinar Bangun IV yang tenggelam di Perairan Danau Toba, Sumatera Utara. AWS Parapat yang terletak di $2,66^{\circ} \mathrm{LU} \quad 98,93^{\circ} \mathrm{BT}$ dipilih sebagai titik pengamatan karena dianggap dapat menginterpretasikan kondisi cuaca di lokasi kejadian yaitu Danau Toba membentang dari $2,35^{\circ}-2,88^{\circ}$ Lintang Utara, $98,52^{\circ}-99,1^{\circ}$ Bujur Timur. Analisis dari data hasil pengamatan sinoptik dari AWS Parapat, serta data pengukuran curah hujan oleh beberapa ARG yang berada di sekitar Danau Toba (ARG Simanindo, ARG Raya, ARG Gurgur, ARG Merek, dan ARG Sidikalang) dilakukan untuk melihat perubahan cuaca secara spasial yang terjadi di sekitar Danau Toba pada saat kejadian.

Tabel 1 menginterpretasikan bagaimana kondisi cuaca di sekitar wilayah Danau Toba (AWS Parapat). Suhu yang tercatat dari pukul 08-12 UTC berkisar $18-19^{\circ} \mathrm{C}$, angin dalam keadaan tenang $(\mathrm{calm})$, dan tidak terjadi penurunan suhu yang fluktuatif dapat mengindikasikan cuaca pada saat itu sedang terjadi hujan. Hal tersebut didukung dengan adanya curah hujan yang tercatat oleh AWS Parapat sebesar 3 mm pada pukul 17.00 WIB (10.00 UTC) bersamaan dengan saat tenggelamnya KM Sinar Bangun IV yang diprakirakan terjadi sekitar pukul 17.00 WIB (10.00 UTC). Tabel 2 menunjukkan jumlah curah hujan yang tercatat oleh beberapa ARG yang ada disekitar wilayah Danau Toba. sehingga dapat disimpulkan pada tanggal 18 Juni 2018, wilayah sekitar Danau Toba diguyur hujan, dengan curah hujan tertinggi teramati oleh ARG Sidikalang. Hujan yang terjadi merupakan dampak dari adanya pertumbuhan awan cumuliform. Hal tersebut dapat dilihat pada analisis satelit.

\section{Analisis Citra Satelit}

Analisis citra satelit dilakukan dengan mengamati suhu puncak awan di setiap lokasi dan pola spasial awan yang terbentuk. Pada awan-awan cumuliform, suhu puncak awan menunjukkan seberapa dingin awan tersebut. Semakin dingin suhu puncak awan maka semakin tinggi puncak awan konvektif yang terbentuk. Pada dasarnya, awan tinggi yang terletak pada ketinggian yang sama dengan puncak awan konvektif juga memiliki suhu yang rendah, namun umumnya itu tidak akan sedingin puncak awan konvektif. Berdasarkan analisis citra satelit pada Gambar 9, perkembangan awan konvektif di sekitar Danau Toba sudah terbentuk mulai pukul 08.00 Z yang ditandai dengan suhu puncak awan $<-50^{\circ} \mathrm{C}$. Pada pukul 10.00 UTC (waktu kejadian), awan kovektif teramati sudah melemah ditandai dengan suhu puncak awan berkisar $>-50^{\circ} \mathrm{C}$. Hal ini mengindikasikan saat tenggelamnya KM Sinar Bangun IV, pertumbuhan awan konvektif masih ada. Hal tersebut dapat terlihat dari cakupan awan secara spasial yang terbentuk 
cukup luas membentang di sebelah barat Danau Toba dengan suhu lebih dingin daro $-50^{\circ} \mathrm{C}$.

$R G B$ Day Microphysics dari Himawari-8 digunakan untuk menunjukkan perkembangan awan-awan konvektif (Gambar 10). Warna merah menunjukkan awan jenis cumuliform yang dapat berkembang menjadi awan yang lebih besar. Ketika pertumbuhan awan cumulus secara vertical maka permukaan awan ditunjukkan lebih kasar lagi dan suhu puncak awan akan lebih dingin dari sebelumnya (Sobajima, dkk., 2011)[8]. Perbedaan dari rata-rata reflektansi visible di suatu area akan terdeteksi dengan ciri-ciri yang disebutkan oleh Sobajima, dkk. (2011)[8] dalam penelitiannya. Gambar 10 menunjukkan pertumbuhan awan konvektif di sekitar wilayah Danau Toba mulai tumbuh dari pukul 09.00 UTC dimana ditandai dengan munculnya awan dengan permukaan kasar (berbentuk seperti gumpalan besar). Pada pukul 10.00 UTC (waktu kejadian), awan teramati lebih besar dari sebelumnya dan luasan awan cukup luas juga. Hal tersebut dapat terlihat dari tutupan awan secara spasila terbentuk di wilayah barat dari Danau Toba.

Gambar 11 menginterpretasikan time series suhu puncak awan menggunakan kanal IR dan VIS. Jika ditinjau dari kanal IR, awan konvektif mulai terbentuk dari pukul 08 UTC kemudian berkembang sampai pukul 09 UTC dan mulai meluruh pukul 10 UTC. Kanal VIS menunjukkan nilai albedo awan dari daerah tutupan awan yang terbentuk. Semakin tinggi nilai albedo yang teramati, maka semakin tebal awan-awan yang terbentuk pada wilayah tersebut. Jika ditinjau dari kanal VIS, albedo awan yang teramati dari pukul 08 UTC sampai 10 UTC berkisar 0.6 sampai 0.8 . Albedo maksimum teramati pada pukul 09 UTC yaitu mencapai 0.8. Hal tersebut menujukkan awan yang terbentuk di sekitar Danau Toba cukup tebal. Tutupan awan yang semakin tebal mengindikasikan peluang terjadinya hujan cukup tinggi. Dari Gambar 9 dan 10, ada indikasi terbentuknya awan konvektif yaitu awan Cumulonimbus. Terlihat dari suhu puncak awan mencapai $-55^{\circ} \mathrm{C}$ dengan nilai albedo mencapai 0.8. Awan Cumulonimbus yang terbentuk berpeluang memicu terjadinya cuaca buruk khususnya berupa hujan lebat dan angin kencang.

\section{KESIMPULAN}

Kondisi cuaca pada saat tenggelamnya Kapal KM Sinar Bangun IV pada tanggal 18 Juni 2018 yaitu terdapat indikasi pertumbuhan awan konvektif di sekitar Danau Toba. Awan-awan tersebut menyebabkan hujan disekitar wilayah Danau Toba. Berdasarkan faktor cuaca, faktor skala global dan regional kurang berpengaruh terhadap pertumbuhan awan konvektif di sekitar Danau Toba. Namun jika ditinjau dari streamline, terdapat sirkulasi siklonik di sebelah barat Pulau Sumatera yang dapat memicu terbentuknya daerah belokan angin (shearline) dimana kondisi SST di sekitar wilayah Sumatera Utara dalam kondisi yang cukup hangat untuk memicu pertumbuhan awan konvektif. Berdasarkan analisis time series suhu puncak awan, terdapat juga penurunan suhu yang signifikan hingga mencapai suhu sekitar $-55^{\circ} \mathrm{C}$.

\section{PENULIS}

\section{Diana Cahaya Siregar}

Dari :

(1) Badan Meteorologi, Klimatologi dan Geofisika, Stasiun Meteorologi Tanjungpinang, Jl. Adi Sucipto KM 12.5, Bandara RHF, Tanjungpinang Timur, Tanjungpinang

2 Sulton Kharisma

Dari :

(1) Badan Meteorologi, Klimatologi dan Geofisika, Stasiun Meteorologi Eltari Kupang, Jalan Rajawali, Bandara Eltari, Penturi, Kupang, Penfui, Maulafa, Kupang

3 Bagas Ega Amirul Haq

Dari :

(1) Badan Meteorologi, Klimatologi dan Geofisika, Sub Bidang Layanan Informasi Meteorologi Penerbangan, Jl. Angkasa I No. 2, Kemayoran, Jakarta Pusat, DKI Jakarta

4 Regina Dara Ninggar

Dari :

(1) Balai Besar Meteorologi, Klimatologi dan Geofisika Wilayah II Tangerang Selatan, Jl. H. Abdulgani No. 5, Cempaka Putih, Ciputat Timur, Kota Tangerang Selatan

\section{Pustaka}

1. Anjasman, 2013, Identifikasi Jenis Awan dan Citra Satelit MTSAT IR1 Menggunakan Logika Fuzzy (Studi Kasus: Banjir 5-6 April 2013 di Kabupaten Aceh Barat, Nagan Raya), Prosiding Seminar Sains Atmosfer 2013, Bandung.

2. Blaschke, T., 2009, Object Based Image Analysis for Remote Sensing, ISPRS Journal of Photogrammetry and Remote Sensing, Elsevier B. V.

3. Hidayat, A. M., Efendi, U., dan Rahmadini, H. N., 2017, Identifikasi Kejadian Hujan Es Berbasis Analisis Faktor Cuaca, Citra Satelit dan Model 
Numerik dengan Aplikasi GrADS (Studi Kasus: Kejadian Hujan Es Tanggal 19 dan 23 April 2017 di Bandung), Seminar Nasional Penginderaan Jauh Ke-4 Tahun 2017.

4. Nugroho, G. A., Sinatra, T., Trismidianto, dan Fathrio, I., 2017, Application of Rain Scanner SANTANU and Transportable Weather Radar in Analyze of Mesoscale Convective System (MCS) Events over Bandung, West Java, IOP Conference Series: Earth and Environmental Science, LISAT 2017.

5. Pandjaitan, B. dan Andersen, P., 2015, Pemanfaatan Data Satelit Cuaca Generasi Baru Himawari 8 Untuk Mendeteksi Asap Akibat Kebakaran Hutan dan Lahan di Wilayah Indonesia (Studi Kasus: Kebakaran Hutan dan Lahan Di Pulau Sumatera dan Kalimantan Pada Bulan September 2015), Prosiding Seminar Nasional Penginderaan Jauh 2015, Bogor.

6. Paski, J. A. I., 2014, Analisis Kejadian Cuaca Ekstrim Tanggal 20 April 2014 di Kota Bengkulu Memanfaatkan Citra Radar dan Satelit, Buletin Balwil // BMKG, 4(9).

7. Samriyanto, 2010, Analisis Citra Satelit dan Radar untuk Membuat Prediksi Cuaca Ekstrim, Buletin $B M K G, 6(4)$.

8. Sobajima, A., Okabe, I., Imai, T., and Izumikawa, Y., 2011, Detection Of Rapidly Developing Cumulus Areas From MTSAT-IR Short Time Interval Images, The 6th European Conference on Severe Storms (ECSS), Palma de Mallorca, Spain.

9. Tjasyono, H. K. B., Lubis, A., Juaeni, I., Ruminta, dan Harijono, S. W. B., 2008, Dampak Variasi Temperatur Samudera Pasifik dan Hindia Ekuatorial Terhadap Curah Hujan di Indonesia, Jurnal Sains Dirgantara, 5(2), 83-95.

10. Zakir, A., Sulistya, W., dan Khotimah, M. K., 2010, Perspektif Operasional Cuaca Tropis, Pusat Penelitian dan Pengembangan BMKG, Jakarta.

11. Tempo Co, 2018, Berita Kapal Tenggelam. [Online].https://nasional.tempo.co/read/ 1102551/pemkab-simalungun-jumlahpenumpang-km-sinar-bangun-188-orang [diakses 15 Juli 2018].

12. Detik News, 2018, Berita Kapal Tenggelam. [Online]. https ://news.detik.com/berita/d4072771/kapal-tenggelam-di-danau-tobasaat-cuaca-buruk?_ga=2.182097825. 70797455 . 15386472481556881929.1503157503) [diakses 15 Juli 2018].

\section{DAFTAR TABEL}

Tabel 1: Pengamatan sinoptik tanggal 18 Juni 2018 yang tercatat AWS Parapat

Sumber: AWS Centre BMKG

\begin{tabular}{|c|c|c|c|c|c|}
\hline $\begin{array}{c}\text { Jam } \\
(\mathbf{U T C})\end{array}$ & $\begin{array}{c}\text { Suhu } \\
\left({ }^{0} C\right)\end{array}$ & $\begin{array}{c}\text { Curah hujan } \\
\text { terukur }(\mathbf{m m})\end{array}$ & $\begin{array}{c}\text { Tekanan } \\
\mathbf{( m b )}\end{array}$ & $\begin{array}{c}\text { Arah } \\
\text { angin }\end{array}$ & $\begin{array}{c}\text { Kecepatan } \\
\text { angin }(\mathbf{m} / \mathbf{s})\end{array}$ \\
\hline 08 & 18.6 & 1.8 & 907.1 & 123.3 & 1.1 \\
\hline 09 & 18.6 & 2.6 & 906.7 & 106.6 & 1.1 \\
\hline 10 & 18.5 & 3 & 906.3 & 99.2 & 1.6 \\
\hline 11 & 18.5 & 3.2 & 905.3 & 111.6 & 1.2 \\
\hline 12 & 18.7 & 3.2 & 904.6 & 115.5 & 1.4 \\
\hline
\end{tabular}

Tabel 2: Curah hujan ARG yang terukur tanggal 18 Juni 2018

Sumber: AWS Centre BMKG

\begin{tabular}{|c|c|c|}
\hline No & Nama Alat & Jumlah curah hujan (mm) \\
\hline 1 & ARG Simanindo & 1.8 \\
\hline 2 & ARG Raya & 0.6 \\
\hline 3 & ARG Gurgur & 0.4 \\
\hline 4 & ARG Merek & 1.8 \\
\hline 5 & ARG Sidikalang & 33.4 \\
\hline 6 & AWS Parapat & 3.4 \\
\hline
\end{tabular}




\section{DAFTAR GAMBAR}
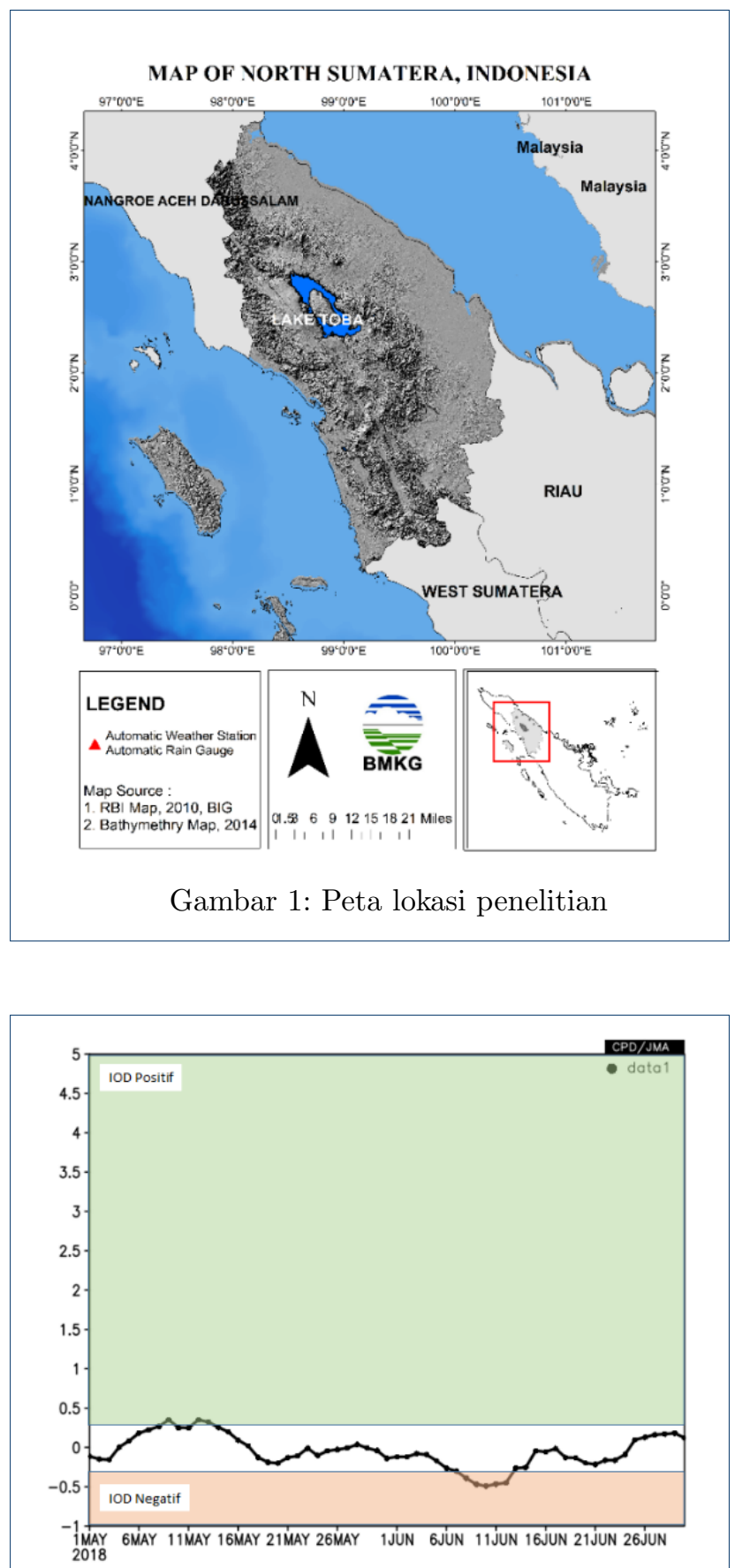

Gambar 2: Grafik indeks IOD tanggal 01 Mei-30 Juni 2018 (iTacs, 2018)
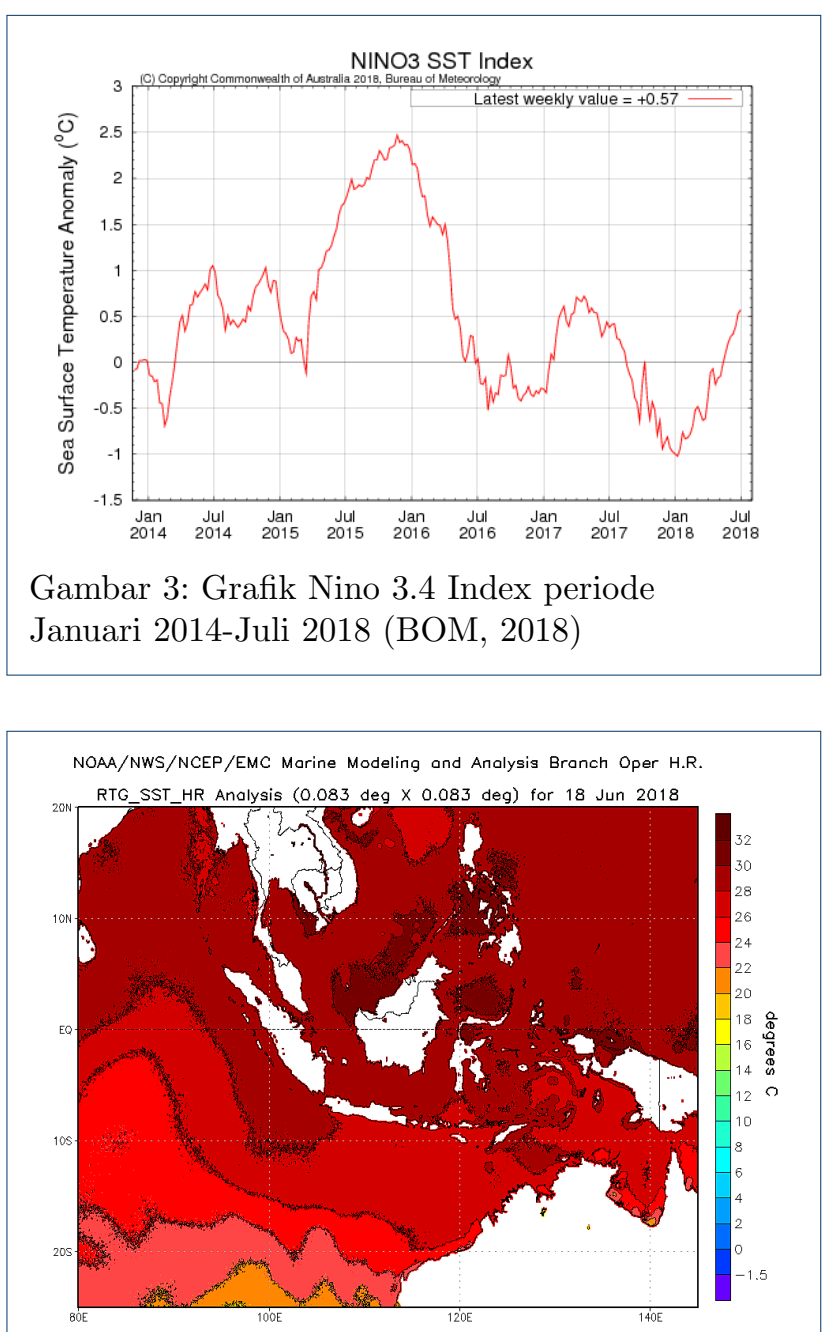

Gambar 4: Analisis suhu permukaan laut tanggal 18 Juni 2018 (NCEP, 2018)

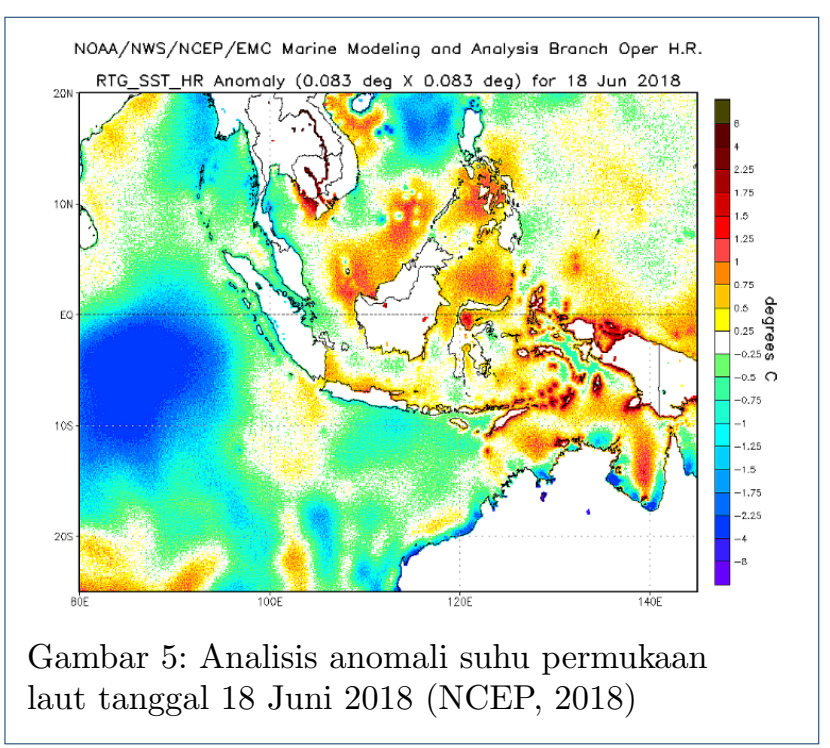



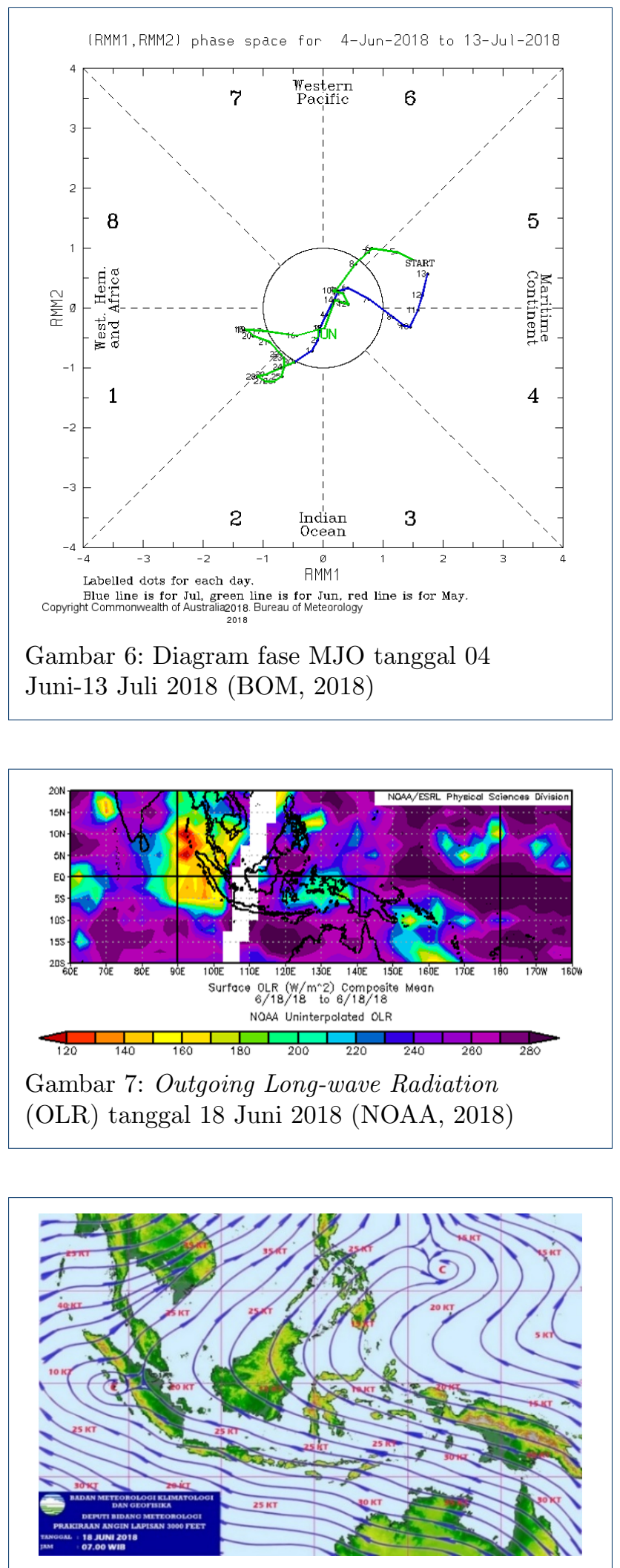

Gambar 8: Streamline tanggal 18 Juni 2018 pukul 00.00 UTC (BMKG, 2018)
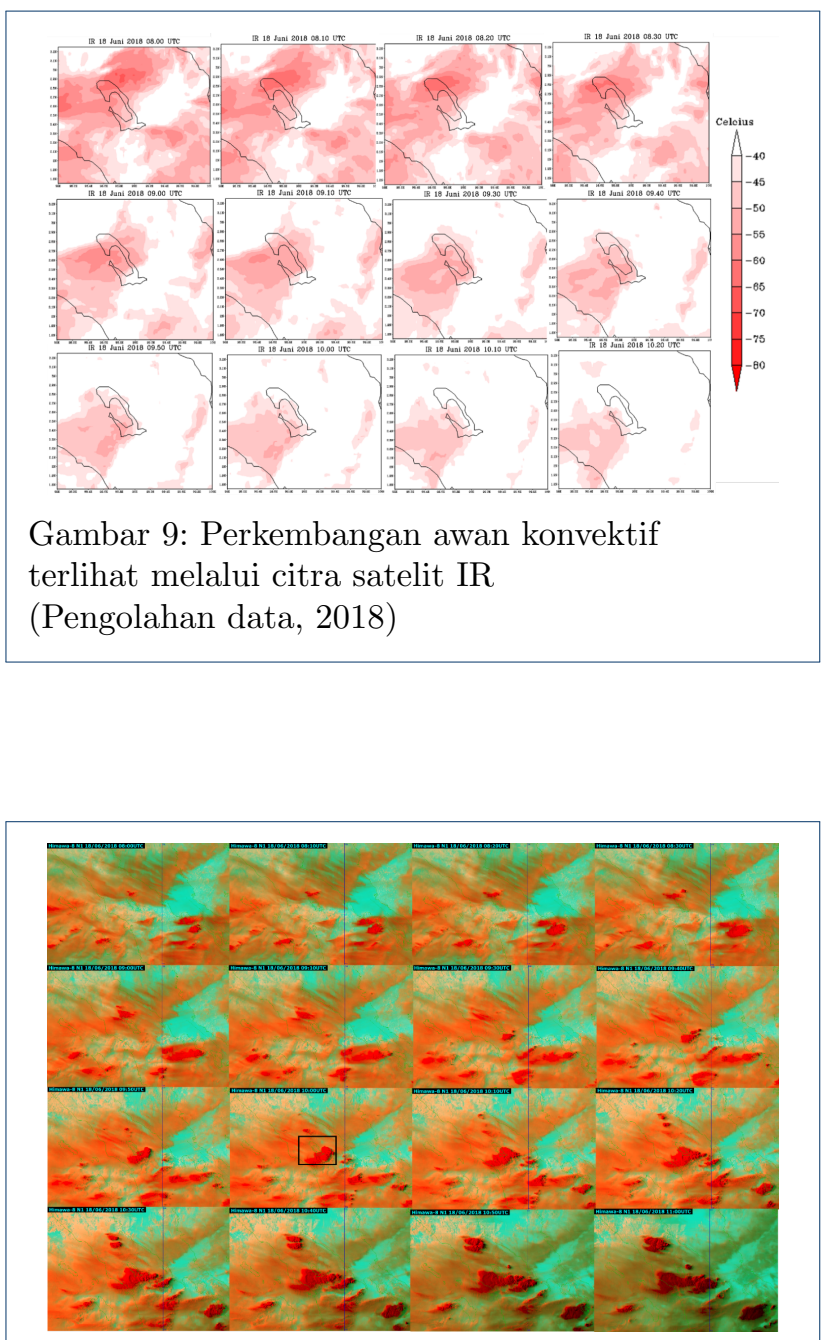

Gambar 10: Perkembangan awan konvektif menggunakan RGB Day Microphysics (Pengolahan data, 2018)

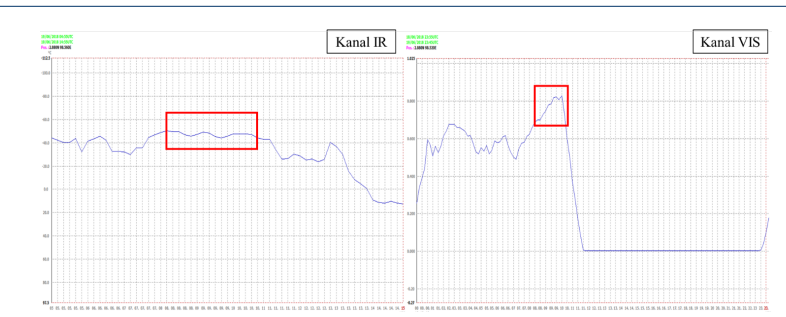

Gambar 11: Time series suhu puncak awan menggunakan kanal IR dan Vis tanggal 18 Juni 2018 (Pengolahan data, 2018) 